\title{
The Effects of Physical Activity on Body Composition and Basal Metabolic Rate of Taiwanese Aboriginal Children during Daily School Time 原住民學童在校時身體活動對身體組成與基礎代謝率的影響
}

\author{
T. H. TSAO C. H. HSU \\ Cheng-Iuan HUANG Huei Ying WU \\ Recreation Sports \& Health Promotion Department, \\ National Pingtung University of Science and Technology, \\ Pingtung, TAIWAN

曹德弘 徐錦興
黃呈原 \\ 台灣國立屏東科技大學 \\ 休閒運動保健系
}

\begin{abstract}
Physical activity is one of the important factors for maintaining weight in adults and children, especially moderate-tovigorous physical activity (MVPA). However, few studies have discussed about physical activity and body composition of aboriginal children, in spite of the differences existing between aboriginal and non-aboriginal children. As a result, the aim of this study was to investigate the effects of physical activity on the body composition and basal metabolic rate (BMR) of Taiwanese aboriginal children. Methods: Thirty boys (aged $10.7 \pm 1.5$ yr with a body-mass index (BMI) of $19.0 \pm 4.2$ $\mathrm{kg} / \mathrm{m} 2$ ) and 26 girls (aged $10.0 \pm 1.5 \mathrm{yr}$ with a BMI of $18.2 \pm 3.7 \mathrm{~kg} / \mathrm{m} 2$ ) participated in this study. Bouchard's physical activity questionnaire was used to measure the physical activity level. The body composition and BMR were determined by a bioelectrical impedance analysis. Results: For all subjects, the period of school time, from leaving home to arriving back home, was totally $530 \pm 38$ minutes. Children engaged in $353.8 \pm 29.7(66 \%), 121.9 \pm 9.7(23 \%), 37.1 \pm 7.5$ (7\%), and $21.4 \pm 7.0(4 \%)$ minutes of sedentary, light, moderate, and vigorous levels of exercise, respectively. The accumulated time of MVPA was significantly higher for boys than for girls. In addition, after the statistical analysis, MVPA was significantly related to the percent body fat and BMR $(-0.79$ and $0.63 ; \mathrm{p}<0.05)$. Conclusions: Sufficient physical activity time, especially MVPA, benefits the maintenance of a normal BMI range for aboriginal children.
\end{abstract}

Key words: moderate-to-vigorous physical activity (MVPA), Bouchard's physical activity questionnaire, percent body fat

\section{摘 要}

身體活動對維持成人與孩童的體重相當重要，特別是中度與激烈程度的身體活動。儘管原住民與非原住民孩童存在著差 異，但原住民兒童身體活動與身體組成的關係卻很少被討論。因此，本研究目的探討身體活動對原住民兒童身體組成與基礎代 謝率的影響。30位原住民男學童 (年齡：10.7 \pm 1.5 歲, 身體質量指數：19.0 $\pm 4.2 \mathrm{~kg} / \mathrm{m}^{2}$ ) 與26位原住民女學童 (年齡： $10.0 \pm 1.5$ 歲, 身體質量指數 $\left.: 18.2 \pm 3.7 \mathrm{~kg} / \mathrm{m}^{2}\right)$ 參與本研究。Bouchard身體活動問卷調查原住民學童不同程度的身體 
活動, 並以生物電阻法原理測量身體組成與基礎代謝率。結果 : 在校時間, 從離家至返家, 總計為530 \pm 38分鐘。在坐式、輕 度、中度、激烈等不同程度的身體活動時間，分別為353.8 \pm 29.7 (66\%) 、 $121.9 \pm 9.7(23 \%) \cdot 37.1 \pm 7.5(7 \%)$ 、 21.4 $\pm 7.0(4 \%)$ 分鐘。男原住民學童在學校累積的中度激烈的身體活動時間顯著多於女原住民學童。再者, 中度激烈的身體活動 時間與原住民學童的體脂肪百分比、基礎代謝率有顯著相關 $(-0.79 、 0.63 ; \mathrm{p}<0.05) \circ$ 結論 : 足夠的身體活動時間, 特別是中 度-激烈程度的身體活動, 將有助於原住民學童維持身體質量指數在正常範圍。

關鍵詞：中度激烈的身體活動、Bouchard身體活動問卷、體脂肪百分比

\section{Introduction}

Weight problems of children have become serious in developed countries in recent years (Hedley et al. 2004; Moreno et al. 2005). Although a lot of money and different strategies have been used to try to curb this increasing trend of children being overweight and obese, a big challenge seems to be continually overcoming the trend of weight increases (Cole, Bellizzi, Flegal, \& Dietz, 2000). Adults are likely to be obese or overweight when they ignored importance of physical activity and diet in childhood. Moreover, many adult chronic diseases, such as type II diabetes, heart disease, and gout, are related to obesity (Pi-Sunyer 1993; Kuczmarski, Flegal, Campbell, \& Johnson, 1994; Troiano, Flegal, Kuczmarski, Campbell, \& Johnson, 1995). As a result, reminding children to pay attention to weight management and encouraging them to have regular habits of physical activity are important for schools, parents, and the children themselves.

The reason to support physical activity is that many observers believe that an increase in physical activity, especially moderate-to-vigorous physical activity (MVPA), can mitigate obesity by boosting energy expenditures (Hill, 2004). In terms of physical activity guidelines for children, research (Kavey et al. 2003; Strong et al. 2005) recommends that children should have at least 60 minutes every day of MVPA. However, a lot of children cannot achieve this recommendation in many countries. If they also don't pay attention to diet, they are likely to be obese or overweight. Several studies (Kanada, Gokhale, \& Rao, 2001; Gilliat-Wimberly, Manore, Woolf, Swan, \& Carroll, 2001; Raguso et al. 2006) have reported the relationships between physical activity and energy in adults; however, few studies on children have been conducted in this field. In addition, an association between physical activity and energy consumption is not clear for all populations (Goran, Hunter, Nagy, \& Johnson, 1997; Westerterp, 2001).
In Taiwan, a trend of increasing weight in children might not be avoided. A study by Huang, Wu, and Yang (2003) reported weight increases of children and adolescents in Taiwan. However, that investigation primarily focused on non-aboriginal Taiwanese children. Recently, a study (Lee \& Huang, 2004) has reported that the weight of aboriginal children has been increasing. In spite of a similar trend of weight increases in aboriginal children, the physical activity of aboriginal children has been less discussed. As a matter of fact, some reasons for the differences between aboriginal and non-aboriginal children should be considered. First, most aboriginal people in Taiwan still retain their traditional cultures and customs in daily life. Second, some aboriginal people still live in mountainous areas or places far from cities. Finally, so far, little information has been reported on the effects of physical activity in aboriginal children on body composition and energy consumption. The twofold goals of this study were to investigate 1) the physical activity levels and time in school for aboriginal children and 2) the effects of physical activity on the body composition and basal metabolic rate (BMR). It was hypothesized that physical activity was related to the body composition and BMR.

\section{Methods}

This study was approved by local hygiene administration. All participants provided written, voluntary informed consent before participation. Moreover, permission was also obtained from all participants' parents or supervisors and the school administration.

Daily school time was defined as the period from leaving home to returning back home after classes had ended and it accounted for the majority of a child's awake period (Fox, Cooper, \& McKenna, 2004). During this period, participants were not allowed to return home. If they forgot to bring something, they could ask a parent 
to bring what they needed or else we would choose another day to do the same measurement if the parent or relative could not bring it to them. The physical activity questionnaire of Bouchard et al. (1983) was used to record physical activity after being revised. An hour was divided into four quarters on this form. Children wrote down the intensity of physical activity each hour for the previous four 15-minute periods according to classifications and examples of activities. Before starting this study, the author explained the meanings and methods on this form to participants and teachers. In addition, the author and his colleagues offered immediate answers when participants could not make a decision as to the level of their physical activity.

The BMI of all subjects (weight $(\mathrm{kg})$ divided by height squared $\left(\mathrm{m}^{2}\right)$ ) and the average percent body fat (measured twice by bioelectrical impedance analysis (Maltron, BF-906, Essex, UK)) were measured in addition to the physical activity measurement. The BMR was measured in the morning after $10 \mathrm{~h}$ of fasting. The height and weight were measured at the same time. These two procedures were performed at least two times. Good reliability was found in the results. All data were reported as the mean \pm standard deviation (SD). Student's t-test was used to analyze the difference between genders. A Correlation analysis was carried out for physical activity and body composition. An alpha level of $<0.05$ was considered significant. SPSS (version 12.0, Chicago, IL, USA) was used for all statistical procedures. In addition, 20 subjects in each group achieved 0.87 for detecting a difference in physical activity time with a significance level (alpha) of 0.05 using a two-sided two-sample t-test after a PASS (Kaysville, UT) sample power analysis.

\section{Results}

This questionnaire has good reliability for measuring physical activity in children and was used in another study (Drapeau et al. 2004). An excellent correlation existed between the first and second measurements for the record of physical activity levels $(r=0.89, \mathrm{p}<0.05)$. In addition, the correlations of measurements of body composition and BMR between two times were also excellent $(r=0.96$ and 0.90 , respectively, $\mathrm{p}<0.05)$.

Table 1 reported the physical characteristics of boys and girls. There were no significant differences in age, BMI, or percent body fat. However, boys' BMR in resting expenditure was significantly higher than that of girls by $2.9 \%$.

In terms of physical activity, Table 2 shows the time of sedentary, light, moderate, and vigorous levels for boys and girls, respectively. Girls had 5.5\% more time in sedentary activities than boys while boys exhibited more time than girls in the light $(+2.2 \%)$ and MVPA $(+10.4 \%)$ portions.

There were no relationships between percent body fat and times in sedentary or light-exercise time periods for boys and girls nor were there relationships of BMR and the time in sedentary and light-exercise time periods for boys and girls. However, for boys and girls, the amount of MVPA was significantly correlated with the percent body fat $(-0.77$ and -0.71 , respectively, $\mathrm{p}<0.05)$. A significant relationship only existed in boys for MVPA and the $\operatorname{BMR}(0.70, \mathrm{p}<0.05)$. Moreover, there was a significant association of MVPA with percent body fat $(-0.79$, $\mathrm{p}<0.05)$ and $\operatorname{BMR}(0.63, \mathrm{p}<0.05)$ when all participants were combined.

Table 1. Age, Body Composition, and Basal Metabolic Rate of Boys and Girls.

\begin{tabular}{lllll}
\hline & Boys $(\mathrm{n}=30)$ & Girls $(\mathrm{n}=26)$ & Sig. & All \\
\hline Age $(\mathrm{yr})$ & $10.7 \pm 1.5$ & $10.0 \pm 1.5$ & NS & $10.4 \pm 1.5$ \\
BMI $\left(\mathrm{kg} / \mathrm{m}^{2}\right)$ & $19.0 \pm 4.2$ & $18.2 \pm 3.7$ & NS & $19.1 \pm 2.0$ \\
Body fat $\%$ & $20.8 \pm 6.7$ & $20.9 \pm 5.8$ & NS & $20.8 \pm 3.0$ \\
BMR $(\mathrm{kca} / \mathrm{day})$ & $1230 \pm 202.5^{*}$ & $1195 \pm 136.0$ & 0.036 & $1216.4 \pm 178.8$ \\
\hline
\end{tabular}

Values are expressed as the mean \pm standard deviation.

BMI, body mass index; BMR, basal metabolic rate.

*Significantly different from the girls. 
Table 2. Time Allocations to Different Physical Activity Levels between Boys and Girls in School.

\begin{tabular}{rllll}
\hline & Boys & Girls & Sig. & All \\
\hline Sedentary (min) & $340.4 \pm 30.3$ & $359.2 \pm 28.1$ & NS & $353.8 \pm 29.7$ \\
Light (min) & $123.3 \pm 11.1$ & $120.5 \pm 10.5$ & NS & $121.9 \pm 9.7$ \\
Moderate (min) & $39.1 \pm 9.4$ & $35.1 \pm 6.9$ & NS & $37.1 \pm 7.5$ \\
Vigorous (min) & $23.3 \pm 8.9$ & $19.5 \pm 6.1$ & NS & $21.4 \pm 7.0$ \\
\hline
\end{tabular}

\section{Discussion}

To our knowledge, this is the first research to provide the time allocated to different physical activity levels during aboriginal children's school time and to investigate the effect of the physical activities at school on aboriginals' body composition and basal metabolism. This study provides the time of different physical activity levels for aboriginal children at school. The time spent in school comprises the greatest part of the day for schoolchildren. In addition, the results of this study showed that the accumulated MVPA time in school was associated with aboriginals' percent body fat and BMR.

Although there were no significant differences in the durations of sedentary, light, moderate, and vigorous levels between boys and girls, boys spent more time in light, moderate, and vigorous activities than girls. This result is in concord with the other published papers (Ridgers, Stratton, \& Fairclough, 2006; Strong et al. 2005), which investigated children's physical activities in schoolbased settings. In addition, boys spent significantly more time in MVPA than girls when the times of moderate and vigorous physical activities were combined (62.4 vs. $54.6 \mathrm{~min}$ ) in the current study. Those other studies also reported that girls spent less time in MVPA than boys. As a result, aboriginal children have a similar phenomenon when compared to other studies.

With respect to the effect of physical activity on body composition, this study showed that sedentary and light levels of physical activity were not significantly related to percent body fat in either boys or girls. However, the combination of accumulated time for moderate and vigorous physical activities was associated with percent of body fat of boys and girls, respectively, even when boys and girls were placed into a group. Consequently, this result is in line with Ruiz et al.'s (2006) and Rowlands, Eston, and Ingledew's (1999) studies, which indicated that not all physical activity levels were related to the percent of body fat. In addition, this study showed that the more time children engaged in MVPA, the less percent body fat they had.

Few studies have reported the relationship between physical activity and BMR in children. The results of this study show that MVPA was significantly related to BMR when boys and girls were combined. But, for relationships of the same parameters, the result for boys differed from that for girls. With respect to studies of these three variables (physical activity, body composition, and BMR) in adult, results (Kanada, Gokhale, \& Rao, 2001; Raguso et al. 2006) supported physical activity influencing the body composition, especially the fat-free mass (FFM), and it was related to BMR. As a result, the FFM plays an important role in influencing the BMR in the abovementioned studies. Based on an adult model, we also measured participants' FFM in the process of taking body composition measurements. However, the results of this study showed that no significant difference existed between boys and girls $(30.6 \pm 7.5$ vs. $30.0 \pm 5.7 \mathrm{~kg})$. As a result, the difference in BMR between boys and girls might not be ascribable to the FFM. In addition to the FFM, several factors, for example race, age, temperature, physical activity, and endocrine gland function can influence BMR. Although there are more than 10 aboriginal tribes in Taiwan, the majority of subjects belonged to the same tribe in this study. A few factors were also considered during research, including age (no significant difference) and health (a normal temperature). However, other factors could not be excluded, and a few limitations are described in next section. From this study, the result of a relationship between physical activity and the BMR was inconsistent in boys and girls. We further analyzed the BMR and physical activity levels by a stepwise regression. In boys and girls, MVPA only 
explained $49 \%$ of variance in BMR for boys and 38\% for girls. But, few similar studies have been conducted on children. As a result, although MVPA might influence aboriginal children's BMR, more studies should be conducted in the future to address this issue.

\section{Limitations}

In addition to some factors relating to body composition, for example, genetics, physical activity, and the environment, diet also influences body composition and energy consumption. However, investigation of the diet was a limitation in this study. As a result, this limitation might make it difficult to explain why boys had a slightly higher BMI and more MVPA time compared to the results of Lee and Huang (2004). In addition, although the ages of boys and girls did not significantly differ, the status of puberty of all participants should have been determined, because changes in body composition might take place in this phase. Perhaps adding this step would help us exclude a confounding factor in future studies.

\section{Conclusions}

The allocation of time engaged in physical activities by aboriginal children at school was investigated in this study. The BMI of aboriginal children is in a normal range according to Lee and Huang's (2004) report. As a result, having sufficient MVPA time is helpful in maintaining aboriginal children's weight. In other words, in addition to reducing sedentary and lower-exercise level times and increasing MVPA time, determining how to diversify activities in school is another direction for schools and teachers. They can encourage children to extend their school experience and education to afterschool activities. This will help children increase energy expenditure and maintain an appropriate weight.

\section{References}

Bouchard, C., Trembly, A., Leblanc, C., Lortie, G., Savard, R., \& Theriault, G. (1983). A method to assess energy expenditure in children and adults. The American Journal of Clinical Nutrition, 37, 461-467.

Cole, T. J., Bellizzi, M. C., Flegal, K. M., \& Dietz, W. H. (2000). Establishing a standard definition for child overweight and obesity worldwide: international survey. British Medical Journal, 320, 1240 - 1243.
Drapeau, V., Despres, J-P, Bouchard, C., Allard, L., Fournier, G., Leblanc, C., \& Trembly, A. (2004). Modification in food-group consumption are related to long-term body-weight changes. The American Journal of Clinical Nutrition, 80, 29-37.

Fox, K., Cooper, A., \& McKenna, J. (2004). The school and promotion of children's health enhancing physical activity: perspectives from the United Kingdom. Journal of Teaching in Physical Education, 23, 336355 .

Gilliat-Wimberly, M., Manore, M. M., Woolf, K., Swan P. D., \& Carroll, S. S. (2001). Effects of habitual physical activity on the resting metabolic rates and body compositions of women aged 35 to 50 years. Journal of the American Dietetic Association, 101, 1181-1188.

Goran, M. I., Hunter, G., Nagy, T. R., \& Johnson, R. (1997). Physical activity related energy expenditure and fat mass in young children. International Journal of Obesity and Related Metabolic Disorders, 21, 171178.

Hedley, A. A.,Ogden, C. L., Johnson, C. L., Carroll, M. D., Curtin L. R., \& Flegal, K. M. (2004). Prevalence of overweight and obesity among US children, adolescents, and adults, 1999-2002. Journal of American Medical Association, 291, 2847-2850.

Hill, J. (2004). Physical activity and obesity. Lancet, 363, 182.

Huang, Y. C., Wu, J. Y., \& Yang, M. J. (2003). Weightfor-height reference and the prevalence of obesity for school children and adolescents in Taiwan and Fuchien areas. Journal of the Chinese Medical Association, 66, 599-606.

Kanada, A. N., Gokhale, M. K., \& Rao, S. (2001). Energy costs of standard activities among Indian adults. European Journal of Clinical Nutrition, 55, 708-713.

Kavey, R. E., Daniels, S. R., Lauer, R. M., Atkins, D. L., Hayman, L. L., \& Taubert, K. (2003). American Heart Association guidelines for primary prevention of atherosclerotic cardiovascular disease beginning in children. The Journal of Pediatrics, 142, 368-372. 
Kuczmarski, R. J., Flegal, K. M., Campbell, S. M., \& Johnson, C. L. (1994). Increasing prevalence of overweight among US adults: the National Health and Nutrition Examination Surveys, 1960 to 1991. Journal of American Medical Association, 272, 205211.

Lee, T. Y., \& Huang, Y. C. (2004). Growth curves of aboriginal children in Taiwan. Acta Paediatrica Taiwanica, 45, 23-29.

Moreno, L. A., Mesana, M. I., Fleta, J., Ruiz, J . R., Gonzalez-Gross, M., Sarria, A., Marcos, A., \& Buneo, M. (2005). Overweight, obesity and body fat composition in Spanish adolescents: The AVENA Study. Annals of Nutrition \& Metabolism, 49, 71-76.

Pi-Sunyer, F.X. (1993). Medical hazards of obesity. Annals of Iinternal Medicine, 119, 655-660.

Raguso, C. A., Kyle, U., Kossovsky, M. P., Roynette, C., Paoloni-Giacobino, A., Hans, D., Genton, L., \& Pichard, C. (2006). A 3-year longitudinal study on body composition changes in the elderly: role of physical exercise. Clinical Nutrition, 25, 573-580.

Ridgers, N. D., Stratton, G., \& Fairclough, S. J. (2006). Physical activity levels of children during school playtime. Sports Medicine, 36, 359-371.

Rowlands, A. V., Eston, R. G., \& Ingledew, D. K. (1999). Relationship between activity levels, aerobic fitness, and body fat in 8- to 10-yr-old children. Journal of Applied Physiology, 86, 1428-1435.

Ruiz, J. R., Rizzo, N. S., Hurtig-Wennlöf, A., Ortega, F. B., Wärnberg, J., \& Sjöstörm, M. (2006). Relation of total physical activity and intensity to fitness and fatness in children: the European Youth Heart Study. The American Journal of Clinical Nutrition, 84, 299303.

Strong, W. B., Malina, R. M., Blimkie, C. J. R., Daniels, S. R., Dishman, R. K., Gutin, B., Hergenroeder, A. C., Must, A., Nixon, P. A., Pivarnik, J. M., Rowland, T., Trost, T., \& Trudeau, F. (2005). Evidence based physical activity for school-age youth. The Journal of Pediatrics, 146, 732-737.
Troiano, R. P., Flegal, K. M., Kuczmarski, R. J., Campbell, S. M., \& Johnson, C. L. (1995). Overweight prevalence and trends for children and adolescents: the National Health and Nutrition Examination Surveys, 1963 to 1991. Archives of Pediatrics \& Adolescent Medicine, 49, 1085-1091.

Westerterp, K. R. (2001). Pattern and intensity of physical activity. Nature, 410, 539.

\section{Correspondence:}

Te Hung TSAO,

Recreation Sports \& Health Promotion Department National Pingtung University of Science and Technology

1 Hseuh-Fu Rd., Nei-Pu Township, Pingtung 912, Taiwan

Tel: $886-8-7703202$, ext. 6484

Fax: 886-8-7740536

Email: thtsao@mail.npust.edu.tw

\section{第一作者通訊：}

曹德弘

休閒運動保健系

國立屏東科技大學

台灣屏東縣內埔鄉學府路1號 (912)

電話： 886-8-7703202, ext. 6484

傳真： 886-8-7740536

Email: thtsao@mail.npust.edu.tw 